\title{
Віддалені результати артропластики та ендопротезування ліктьового суглоба у хворих з наслідками травм
}

\begin{abstract}
Мета роботи: порівняння функціональних результатів, отриманих від артропластичних процедур та ендопротезування у хворих із наслідками травм ліктьового суглоба.

Матеріали і методи. Під спостереженням перебували 53 пацієнти з тяжкими наслідками травм ліктьового суглоба. Хворі були розділені на 2 групи. Перша група - 39 пацієнтів (73,58 \%), яким виконували інтерпозиційну (12 пацієнтів) артропластику та моделюючу резекційну артропластику з одномоментним артролізом без використання інтерпозиційних матеріалів (27 пацієнтів). Другу групу склали 14 пацієнтів (26,42 \%) після ендопротезування ліктьового суглоба, яких було обстежено в терміни від 2-х до 9-ти років після операції.

Результати досліджень та їх обговорення. Аналіз віддалених результатів підтвердив, що інтерпозиційна та резекційномоделююча артропластика $є$ ефективним способом відновлення рухів в ліктьовому суглобі, однак з часом функціональні результати мають тенденцію до погіршення за рахунок збільшення больового синдрому та нестабільності. При виконанні артропластики ліктьового суглоба у хворих із тяжкими наслідками травми ліктьового суглоба відмінні та хороші результати склали 38,1 \%, 47,62 \% - задовільні та 14,28 \% - незадовільні. Ендопротезування ліктьового суглоба є найбільш дієвим засобом в лікуванні тяжких післятравматичних деформацій та анкілозів ліктьового суглоба і дозволяє отримати відмінні та хороші результати лікування в 85,72 \% випадків. Оптимальним для лікування тяжких післятравматичних деформацій та анкілозів ліктьового суглоба є використання напіврозімкнутих конструкцій, що дозволяє проводити ранню дозовану активну реабілітацію. Нестабільність ліктьового суглоба, яка спостерігалась у всіх пацієнтів після артропластики та наявність залишкової згинально-розгинальної контрактури ліктьового суглоба, є передумовами до швидкого прогресування остеоартрозу.
\end{abstract}

Ключові слова: артропластика; ендопротезування; ліктьовий суглоб.

Постановка проблеми і аналіз останніх досліджень та публікацій. Відновлення функції ліктьового суглоба є складною та важливою проблемою. Складність та важливість пов’язана з особливою біомеханікою ліктьового суглоба, в якій беруть участь кілька суглобів, а рух ліктя має вирішальне значення для руху верхньої кінцівки: втрата 50 \% функції ліктьового суглоба дорівнює втраті 80 \% глобальної функції верхньої кінцівки [12].

Тяжкість наслідків травм ліктьового суглоба пов'язана в ряді випадків і з нераціональною та не завжди повною хірургічною допомогою на початкових етапах лікування. За даними багатьох авторів, пошкодження ліктьового суглоба займають перше місце за числом післятравматичних ускладнень, кількість яких коливається від 12 до 50 \%, а майже в 30 \% випадків приводить до стійкої інвалідизації пацієнтів [6]. Кількість незадовільних результатів після лікування внутрішньосуглобових ушкоджень ліктьового суглоба залишається достатньо високою і складає від 18,5 до 45,6 \% [2].

3 розвитком ендопротезування ця проблема отримала новий та ефективний напрямок свого рішення. Однак не у всіх випадках і не завжди ми можемо виконати вищезгадану процедуру. Мова перш за все йде про молодих пацієнтів або про хворих із високим ризиком гнійно-некротичних ускладнень. Привертає увагу, що проблема артро- пластики ліктьового суглоба залишається актуальною і до сьогодні $[1,5,7,11]$. Автори в багатьох випадках обговорюють результати інтерпозиційної артропластики з використанням різних засобів [1, 5, 7, 10, 11, 12]. Тому важливим є порівняння функціональних результатів, отриманих від артропластичних процедур та ендопротезування у хворих із наслідками травм ліктьового суглоба, що і стало метою нашого дослідження.

Матеріали і методи. Спостерігали 53 пацієнти з тяжкими наслідками травм ліктьового суглоба. Хворі були розділені на 2 групи. Перша група - 39 пацієнтів (73,58 \%) (чоловіків 22, жінок 17, се-

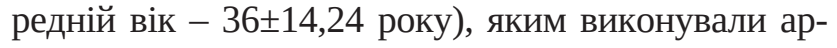
тропластичні втручання на ліктьовому суглобі. Серед них інтерпозиційна артропластика (підгрупа А) - 12 пацієнтів (30,77 \%), і 27 пацієнтів (69, 23 \%) (підгрупа В), яким проводили моделюючу та резекційну артропластику разом із артролізом без використання інтерпозиційних матеріалів.

У 14 пацієнтів першої групи (35,9%) спостерігався частковий або повний кістковий анкілоз ліктьового суглоба, у 10 хворих - фіброзний анкілоз (25,64 \%), у всіх інших хворих першої групи рухи по дузі не перевищували 20-25 градусів (38,46 \%).

У підгрупі А першої групи у пацієнтів як інтерпонуючий матеріал використовували Тunica 
albuginea testis bobinus в 3-х випадках (25,0 \%), в 5 випадках - Fascia lata (41,67 \%), в 4-х випадках медичний кістковий віск (33,33 \%).

В обох підгрупах першої групи операційне втручання було спрямоване на моделювання суглобових поверхонь максимально наближено до анатомічних, крім того, воно супроводжувалось роз'єднанням та видаленням рубців між суглобовими поверхнями, видаленням головки променевої кістки в 5 випадках (12,82 \%) (у 7 випадках $(17,95 \%)$ головка променевої кістки була видалена на попередніх етапах лікування), видаленням фрагментів вінцевого виростка в 4 випадках $(10,26 \%)$, частковою резекцією олекранона в 8 випадках (20,51 \%), видаленням параосальних осифікатів у 12 випадках (30,77 \%), невролізом та транспозицією ліктьового нерва у 8 випадках (20,51 \%). Передню капсулотомію виконували в 10 пацієнтів (25,64 \%), а накладання апарата Волкова-Оганесяна для відновлення обсягу рухів - в 7 випадках (17,95 \%). Апарат Волкова-Оганесяна накладали на термін від 2-х до 8-ми тижнів 3 метою збільшення об’єму рухів в оперованому ліктьовому суглобі.

Слід зазначити, що повний обсяг рухів у ліктьовому суглобі вдалося досягнути лише у половини пацієнтів першої групи. У 48,71 \% відразу після операції спостерігали обмеження рухів, яке складало від 10-15 до 20-25 градусів по дузі. У двох пацієнтів (5,12 \%) спостерігали вторинне загоєння післяопераційної рани. У пацієнтів I групи не застосовували ранню активну дозовану рухову реабілітацію.

У другу групу увійшли 14 пацієнтів (26,42 \%) після ендопротезування ліктьового суглоба, яких було обстежено в терміни від 2-х до 9-ти років після операції. Пацієнти зверталися в клініку на ендопротезування в терміни від 4-х міс. до 5 років після травми. У більшості хворих були тяжкі переломи дистальних відділів плечової кістки (B3, С2, С3 за класифікацією АО), а двоє пацієнтів (14, 29 \%) мали післятравматичний дефект дистального епіметафізу плечової кістки, що в подальшому вимагало індивідуального протезування ліктьового суглоба. Вік хворих коливався від 21 до 74 років (в середньому 44,28 17,37 року). При зверненні у всіх пацієнтів спостерігали значне порушення функції ліктьового суглоба, у одного хворого сформувався кістковий анкілоз (7,14 \%), у 7 пацієнтів - фіброзний анкілоз (50,0 \%), у всіх інших обстежених об'єм рухів не перевищував 20-25 градусів (6 хворих - 42,86 \%). У 2-х хворих (14,29 \%) післятравматичний дефект дистального епіметафіза плечової кістки супроводжував- ся посттравматичним дефектом м'яких тканин в області ліктьового суглоба та ушкодженням триголового м'яза, що потребувало на попередньому етапі вільної мікрохірургічної пересадки шкірном'язового трансплантату найширшого м'яза спини. У 5 пацієнтів (35,71 \%) при зверненні спостерігали компресійно-ішемічну невропатію ліктьового нерва, а у двох пацієнтів - його ушкодження (14,29 \%), внаслідок чого в подальшому їм було виконано пластику дефекту.

11 пацієнтам (78,57 \%) був встановлений шарнірний напіврозімкнутий ендопротез фірми Stryker “Solar”, одному (7,14 \%) - безшарнірний ендопротез тієї ж фірми “Sauter” і двом хворим проводилось ендопротезування індивідуально виготовленим протезом (14,29 \%). Операційне втручання при постановці ендопротеза проводили із стандартного доступу 3 обов'язковою мобілізацією та контролем ліктьового нерва в операційній рані. Обережно роз'єднували ушкоджені суглобові поверхні та послідовно встановлювали ліктьовий та плечовий компоненти, дотримуючись викладених в протоколі осьових співвідношень. Зазвичай труднощі при визначенні анатомічних орієнтирів виникали при наявних кісткових та фіброзних анкілозах з явищами післятравматичних дефектів та деформацій суглобових поверхонь і при значній кількості навколосуглобових осифікатів. Все це ускладнювало прецезійне встановлення плечового компонента, тому в ході операційного втручання проводили максимально повне видалення параосальних напластувань, що дозволяло наблизити форму дистального епіметафізу плеча до норми.

Як зазначалося вище, двом пацієнтам (14,29 \%), що поступили в клініку з дефектом кісткової та м'яких тканин в зоні ліктьового суглоба, проводилось етапне лікування, що включало на першому етапі заміщення шкірно-м'язового дефекту шляхом вільної пересадки найширшого м'яза спини, на другому етапі - встановлення індивідуального напіврозімкнутого ендопротеза, на третьому етапі - відновлення ліктьового і серединного нервів та триголового м'яза плеча. В одному із двох випадків, у зв'язку із значним дефектом ліктьової кістки, пацієнту було проведене плечопроменеве ендопротезування.

Пацієнти другої групи в післяопераційному періоді проходили курс активної дозованої рухової реабілітації $з$ методикою, розробленою в нашій клініці [3].

Результати артроплатики та ендопротезування оцінювали за системою Mayo Elbow Performance Score, яка включала бальну оцінку за чотирма основним напрямкам: інтенсивність больового 
синдрому, рухи в ліктьовому суглобі, стабільність ліктьового суглоба і функція ліктьового суглоба.

Відмінним результатом вважалося, коли в ході оцінки функціональних можливостей пацієнт набирав більше або 90 балів, добрим - 75-89 балів, задовільним - 60-74 бали і незадовільним - менше 60 балів.

Результати досліджень та їх обговорення. Результати артропластики та артролізу в першій групі пацієнтів вивчали в терміни від 6 місяців до 18 років. Віддалені результати в першій групі вдалось вивчити лише у 21 пацієнта (53,85 \%). В підгрупі А (інтерпонуюча артропластика) вдалося обстежити 9 хворих, у яких отримано добрі результати лікування у 3-х (33,33 \%), задовільні у 4-х (44,44 \%), незадовільні - у 2-х пацієнтів (22,23 \%). Підгрупа В (моделююча, резекційна артропластика) - 12 хворих обстежено: відмінний результат - один пацієнт (8,33 \%), добрі результати - у 4-х (33,34 \%), задовільні - у 6 хворих (50,0 \%), незадовільний результат у одного (8,33 \%).

У всіх пацієнтів першої групи спостерігалась нестабільність ліктьового суглоба, яка визначалась при клінічному обстеженні, а у 2-х пацієнтів (9,52 \%) були присутні явища вивихування. У 18 обстежених пацієнтів (85,71 \%) спостерігали зменшення обсягу рухів протягом 3-5 років після артропластики, а 4 пацієнта (19,04 \%) звертали увагу на посилення больового синдрому. Гірші результати спостерігали у хворих, яким не вдалося на операційному столі відновити повний обсяг рухів. При зіставленні ступеня нестабільності та об’єму рухів була виявлена тенденція: більший обсяг рухів - більша нестабільність в ліктьовому суглобі.

Результати ендопротезування в другій групі залежали від ступеня тяжкості попередніх травматичних ушкоджень, а також від того, наскільки пацієнт був налаштований на дозоване активне відновлення рухів в ліктьовому суглобі. Обмеження розгинання в 25-30 градусів спостерігалось у 4-х пацієнтів (28,57 \%). Рухи в межах від 20 до 90 градусів спостерігали у 6 пацієнтів (42, 86 \%). У одного хворого (7,14 \%) досягли обсягу рухів від 40 до 90 градусів. У пацієнта з кістковим анкілозом ліктьового суглоба, що став наслідком гнійно-некротичного процесу було застосовано розімкнутий ендопротез “Sauter". На другому році після ендопротезування у цього хворого виникла асептична, а потім септична нестабільність і нагноєння ендопротеза. Після видалення ендопротеза у пацієнта залишився обсяг активних безболісних рухів 30-35 градусів по дузі, що дозволило йому покращити свої можливості в самообслуго- вуванні та побуті. Незадовільний результат ендопротезування в цьому випадку, на нашу думку, був пов’язаний з помилкою у виборі розімкнутої конструкції ендопротеза, яка не дає можливості достатньої стабілізації ліктьового суглоба в пацієнтів із наслідками травм.

У 2-х пацієнтів (14,29 \%) через 1,5 та 2 роки після ендопротезування виникли явища асептичної нестабільності плечового компонента ендопротеза. Проблему вдалось усунути шляхом заміни плечового компонента ендопротеза на більший за розміром. На нашу думку, провокуючим моментом у виникненні нестабільності могло бути неповне усунення згинальної контрактури в ліктьовому суглобі, що в подальшому призвело до перенавантаження саме плечового компонента ліктьового ендопротеза.

Достатньо хороший обсяг рухів протягом 5 років після ендопротезування (від 20 до 90 градусів) зберігався у 2-х пацієнтів з дефектами дистального епіметафізу плечової кістки, котрим довелось виконати індивідуальне ендопротезування та попереднє заміщення дефекту м’яких тканин вільним шкірно-м'язовим мікрохірургічним трансплантатом. В ході ортопедичної реконструкції вдалося не тільки виконати ендопротезування, а і відновити функцію травмованого триголового м’яза, що, на нашу думку, і стало одним із компонентів досягнення успішного результату.

Оцінюючи результати протезування за системою Mayo Elbow Performance Score, отримали відмінні показники у 4-х пацієнтів (28,57\%), хороші у 8 хворих (57,15 \%), задовільні - у одного (7,14\%) і незадовільні - у одного пацієнта (7,14 \%).

Аналізуючи відновлення функції ліктьового суглоба після ендопротезування, привертає увагу факт, що при постановці стандартизованих ендопротезів Solar очікувано гірші результати отримали у пацієнтів з наявністю осьових деформацій та значними параосальними кістковими розростаннями, тоді як при постановці індивідуальних ендопротезів, в більш складних випадках при тяжких ушкодженнях м’яких тканин вдалося зберегти майже повний обсяг рухів.

Важливим, на нашу думку, в отриманні адекватних функціональних результатів $є$ рання дозована активна післяопераційна реабілітація, яка $є$ запорукою збереження обсягу рухів в ліктьовому суглобі. Така рання реабілітація можлива лише за умови використання напіврозімкнутих конструкцій. Активні рухи в таких випадках розпочинали на 3-4 день після операції. В початковому періоді (від 3-го до 10 дня після операції) активні рухи складали від 1 до 4-5 циклів на добу, на другому тижні 
кількість циклів зростала до 4-8. Критерієм збільшення циклів рухової активності було поступове зменшення набряку та больового синдрому [3].

Порівнюючи віддалені результати артропластики та ендопротезування, привертає увагу факт, що попри те, що вихідна тяжкість суглобових ушкоджень та втрата обсягу рухів в ліктьовому суглобі була подібна в обох групах на початку лікування, результати в цих групах відрізнялись кардинально. Відмінні та добрі результати в групі, де проводилась артропластика ліктьового суглоба, склали лише 38 \%, тоді як в групі, де проводилось ендопротезування - 86 \%.

На відміну від Maritz Laubsher, ми не отримали в першій групі хворих (де проводилась інтерпозиційна та резекційно-моделююча артропластика) значної кількості добрих результатів та зростання функції ліктьового суглоба з 42 до 76 балів за системою Mayo Elbow Performance Score у більшості пацієнтів [9]. Ми не спостерігали стрімкого зростання функції ліктя за MEPS з 64 до 82 балів при інтерпозиційній пластиці, як було у хворих із радіокапітулярним та радіоульнарним артрозом у спостереженнях Yaser Baghdadi [8]. Велика кількість задовільних та незадовільних результатів при артропластиці в нашому матеріалі пов' язана як з вихідною тяжкістю ушкоджень ліктьового суглоба (кістковий та фіброзний анкілоз у 61,54 \% хворих), так і відсутністю чіткої дозованої системи післяопераційної реабілітації в цій групі хворих. Привертає увагу, що у хворих першої групи після інтерпозиційної та моделюючо-резекційної артропластики спостерігалось зменшення обсягу рухів через $3-5$ років після операції та збільшення рівня больового синдрому, що збігається з даними А. В. Амбросенкова [1]. За даними автора, резекційна артропластика дозволяє забезпечити відмінні і хороші результати лікування через 3 роки у 56 \% хворих, але через 7 років незадовільні результати складають 50 \% від загальної кількості клінічних спостережень.

\section{СПИСОК ЛІТЕРАТУРИ}

1. Амбросенков А. В. Артропластика локтевого сустава (резекционная и эндопротезирование различными конструкциями) при его повреждениях и заболеваниях (клиникоэкспериментальное исследование) : автореф. дисс. на соискание науч. степени канд. мед. наук : спец. 14.00.22 “Травматология и ортопедия” / А. В. Амбросенков. - СПб., 2008. -23 с.

2. Бойко И. В. Медицинская реабилитация больных с последствиями травм и заболеваний локтевого сустава / И. В. Бойко. - Дніпропетровськ : Пороги, 2006. - 155 с.

3. Рухова реабілітація хворих після операції з приводу післятравматичної контрактури ліктьового суглоба / I. М. Курінний, О. С. Страфун, О. В. Долгополов, А. С. Герасименко //
Найбільш часто погіршення функції ліктьового суглоба у віддаленому періоді спостерігалось у хворих, котрим не вдалося після операції в повному обсязі відновити об'єм рухів в ліктьовому суглобі. Вважаємо, що активне навантаження ліктьового суглоба після артропластичних операцій, де не повністю усунена згинально-розгинальна контрактура ліктьового суглоба та присутня його нестабільність, $є$ передумовою швидкого прогресування остеоартрозу, що підтверджують, в тому числі, і наші біомеханічні дослідження [4].

Висновки. 1. Інтерпозиційна та резекційномоделююча артропластика $є$ ефективним способом відновлення рухів в ліктьовому суглобі, однак з часом функціональні результати мають тенденцію до погіршення за рахунок збільшення больового синдрому та нестабільності.

2. При виконанні артропластики ліктьового суглоба у хворих із тяжкими наслідками травм ліктьового суглоба відмінні та хороші результати отримали в $38,1 \%$ випадків, задовільні результати склали 47,62 \%, окрім того, було 14,28 \% незадовільних результатів.

3. Ендопротезування ліктьового суглоба $є$ найбільш дієвим засобом в лікуванні тяжких післятравматичних деформацій та анкілозів ліктьового суглоба і дозволяє отримати відмінні та хороші результати в $85,72 \%$ спостережень.

4. Оптимальними для лікування тяжких післятравматичних деформацій та анкілозів ліктьового суглоба $є$ використання напіврозімкнутих конструкцій, що дозволяє проводити ранню дозовану активну реабілітацію.

5. Нестабільність ліктьового суглоба, яка спостерігалась у всіх пацієнтів після артропластики та наявність залишкової згинально-розгинальної контрактури ліктьового суглоба, є передумовами до швидкого прогресування остеоартрозу ліктьового суглоба.

Клінічна хірургія. - 2017. - № 11. - С. 65-69.

4. Лазарєв I. А. Біомеханічний розрахунок навантаження на структури ліктьового суглоба при його одномоментній мануальній редресації / І. А. Лазарєв, О. С. Страфун, М. В. Скибан // Травма. - 2018. - Т. 19, № 5. - С. 41-49.

5. Меркулов В. Н. Артропластика при лечении посттравматических контрактур и анкилозов локтевого сустава у детей / В. Н. Меркулов, Д. А. Дергачев, А. И. Дорохин // Российский вестник детской хирургии, анестезиологии и реаниматологии. - 2014. - Т. 4, № 3. - С. 58-66.

6. Прохоренко В. М. Эндопротезирование локтевого сустава / В. М. Прохоренко, А. Б. Слободской. - Новосибирск : Наука, 2010. - 79 с. 


\section{З ДОСВІДУ РОБОТИ}

7. Лечение остеоартроза локтевого сустава / А. П. Ратьев, К. А. Егиазарян, Е. А. Жаворонков, В. С. Мельников // Вопросы реконструктивной и пластической хирургии. 2014. - T. 2 (49). - C. 50-60.

8. Baghdadi Y. Anconeus interposition arthroplasty: mid- to long-term results / Y. Baghdadi, B. Morrey, J. Sanchez-Sotelo // Clin. Orthop. Relat. Res. - 2014. - Vol. 472 (7). - P. 2151-2161. 9. A retrospective review of a series of interposition arthroplasties of the elbow / M. Laubscher, A. J. H. Vochteloo, A. A. Smit [et al.] // Shoulder Elbow. - 2014. - Vol. 6 (2). - P. 129-133.

10. Stiff elbow treatment by interposing arthroplasty associated to hinged external fixator / A. Miyazaki, M. Fregoneze, P. Santos [et al.] // Rev. Bras. Ortop. - 2009. - Vol. 44 (4). P. 336-341.

11. The waterfall fascia lata interposition arthroplasty "Grika Technique" as treatment of posttraumatic osteoarthritis of the elbow in a high-demand adult patient: Validity and reliability / G. Rollo, R. Rotini, D. Eygendaal [et al.] // Case Rep. Orthop. - 2018. - Vol. 2018. - P. 1-7.

12. Treatment of stiff elbow in young patients with interpositional arthroplasty for mobility: Case series. / R. Sivakumar, V. SomaSheker, P. K. Shingi [et al.] // J. Orthop. Case Rep. - 2016. - Vol. 6 (4). - P. 49-52.

\section{REFERENCES}

1. Ambrosenkov, A.V. (2008). Artroplastika loktevogo sustava (rezektsionnaya i endoprotezirovaniye razlichnymi konstruktsiyami) pri yego povrezhdeniyakh i zabolevaniyakh (klinikoeksperimentalnoye issledovaniye) [Arthroplasty of the elbow joint (resection and endoprosthetics with various constructions) for its injuries and diseases (clinical and experimental study)]. Candidate's thesis. Sanint Petersburg [in Russian].

2. Boyko, I.V. (2006). Meditsinskaya reabilitatsiya bolnykh s posledstviyami travm i zabolevaniy loktevogo sustava [Medical rehabilitation of patients with consequences of injuries and diseases of the elbow joint]. Dnipropetrovsk: Porogi [in Russian]. 3. Kurinnyi, I.M., Strafun, O.S., Dolhopolov, O.V., \& Herasymenko, A.S. (2017). Rukhova reabilitatsiia khvorykh pislia operatsii z pryvodu pisliatravmatychnoi kontraktury liktovoho suhloba [Motor rehabilitation of patients after surgery for posttraumatic contracture of the elbow joint]. Klinichna khirurhiia - Clinical Surgery, 11, 65-69 [in Ukrainian].

4. Lazariev, I.A., Strafun, O.S., \& Skyban, M.V. (2018). Biomekhanichnyi rozrakhunok navantazhennia na struktury liktovoho suhloba pry yoho odnomomentnii manualnii redresatsii [Biomechanical calculation of the load on the structures of the elbow joint with its one-time manual redress]. Travma - Trauma, 19, 5, 41-49 [in Ukrainian].

5. Merkulov, V.N., Dergachev, D.A., \& Dorokhin, A.I. (2014). Artroplastika pri lechenii posttravmaticheskikh kontraktur i ankilozov loktevogo sustava u detey. Rossiyskiy vestnik detskoy khirurgii, anesteziologii i reanimatologii - Russian Journal of Pediatric Surgery, Anesthesiology and Resuscitation, 4, 3, 58-66 [in Russian].

6. Prokhorenko, V.M., \& Slobodskoy, A.B. (2010). Endoprotezirovaniye loktevogo sustava [Endoprosthetics of the elbow joint]. Novosibirsk: Nauka [in Russian].

7. Ratyev, A.P., Yegiazaryan, K.A., Zhavoronkov, Ye.A., \& Melnikov, V.S. (2014). Lecheniye osteoartroza loktevogo sustava [Treatment of osteoarthritis of the elbow joint]. Voprosy rekonstruktivnoy i plasticheskoy khirurgii - Questions of Reconstructive and Plastic Surgery, 2 (49), 50-60 [in Ukrainian]. 8. Baghdadi, Y., Morrey, B., \& Sanchez-Sotelo, J. (2014). Anconeus Interposition Arthroplasty: Mid- to long-term results. Clin. Orthop. Relat. Res., 472 (7), 2151-2161.

9. Laubscher, M., Vochteloo, A.J.H., Smit, A.A., Vrettos, B.C., \& Roche, S.J.L. (2014). A retrospective review of a series of interposition arthroplasties of the elbow. Shoulder Elbow, 6 (2), 129-133.

10. Miyazaki, A., Fregoneze, M., Santos, P., Andrade da Silva, L., Gennaro, N., \& Checchia, S. (2009). Stiff elbow treatment by interposing arthroplasty associated to hinged external fixator. Rev. Bras. Ortop., 44 (4), 336-341.

11. Rollo, G., Rotini, R., Eygendaal, D., Pichierri, P., Prkic, A., Bisaccia, M., ... \& Meccariello, L. (2018). The waterfall fascia lata interposition arthroplasty "Grika Technique" as treatment of posttraumatic osteoarthritis of the elbow in a high-demand adult patient: Validity and reliability. Case Rep. Orthop., 22, 2018, 8253732. doi:10.1155/2018/8253732.

12. Sivakumar, R., SomaSheker, V., Shingi, P.K., Vinoth, T., \& Chidambaram, M. (2016). Treatment of stiff elbow in young patients with interpositional arthroplasty for mobility: Case series. J. Orthop Case Rep., 6 (4), 49-52.

Отримано 11.01.2019. 


\title{
O. S. STRAFUN
}

Institute of Traumatology and Orthopedics of the National Academy of Medical Sciences of Ukraine

\section{LONG-TERM RESULTS OF ARTHROPLASTY AND ENDOPROSTHETIC REPLACEMENT OF THE ELBOWJOINT IN PATIENTS WITH SEVERE POSTTRAUMATIC CONSEQUENCES}

The aim of the work: comparison of functional results obtained from interposition arthroplasty and endoprosthetics replacement of the elbow in patients with the consequences of injuries of the elbow joint.

Materials and Methods. 53 patients with severe consequences of elbow joint injuries were operated and followed up. The patients were divided into two groups. The group 1 - 39 patients (73.58 \%) were treated with interposition arthroplasty (12 patients) and modeling resection arthroplasty with elbow joint arthrolysis without interposition materials usage (27 patients). The group 2 included 14 patients ( $26.42 \%$ ) after endoprosthetics replacement of the elbow joint, were examined in the 2 to 9 years after the operation.

Results and Discussions After analyzing our results, the following conclusions were made: interposition and resection arthroplasty are effective means/instruments to recover movements in the elbow joint, but in the long period follow up, functional results have tendency to decrease due to increasing pain syndrome and instability of the elbow. After interposition and resection arthroplasty of the elbow joint in patients with severe consequences of elbow injury, excellent and good results were obtained in $38.1 \%$ of patients, satisfactory - in $47.62 \%$ and unsatisfactory - in $14.28 \%$ of patients. Endoprosthetics replacement of the elbow joint is the most effective mean of treating severe post-traumatic deformities and ankylosis of the elbow joint and allows to receive excellent and good treatment results in $85.72 \%$ of cases. The optimal treatment of severe post-traumatic deformities and ankylosis of the elbow joint is the use of Semiconstrained prosthesis, which allows for early dosed active rehabilitation. The instability of the elbow joint, which was observed in all patients after interposition and resection arthroplasty, and the presence of residual flexion-extension contracture of the elbow joint, are preconditions for the rapid progression of the elbow osteoarthrosis.

Key words: arthroplasty; endoprosthetics; elbow joint.

А. С. СТРАФУН

ГУ “Институт травматологии и ортопедии НАМН Украины"

\section{ОТДАЛЕННЫЕ РЕЗУЛЬТАТЫ АРТРОПЛАСТИКИ И ЭНДОПРОТЕЗИРОВАНИЯ ЛОКТЕВОГО СУСТАВА У БОЛЬНЫХ С ПОС.ЛЕДСТВИЯМИ ТРАВМ}

\begin{abstract}
Цель работы: сравнение функциональных результатов, полученных от артропластических процедур и эндопротезирования у больных с последствиями травм локтевого сустава.

Материалы и методы. Под наблюдением были 53 пациента с тяжелыми последствиями травм локтевого сустава. Больные были разделены на 2 группы. Первая группа - 39 пациентов (73,58 \%), которым выполнялась интерпозиционная артропластика (12 пациентов) и моделирующая резекционная артропластика с одномоментным артролизом без использования интерпозиционных материалов (27 пациентов). Во вторую группу вошли 14 пациентов (26,42 \%) после эндопротезирования локтевого сустава, которых было обследовано в сроки от 2-х до 9-ти лет после операции.

Результаты исследований и их обсуждение. Анализируя отдаленные результаты, пришли к следующим выводам: интерпозиционная и резекционно-моделирующая артропластика являются эффективными способами восстановления движений в локтевом суставе, однако со временем функциональные результаты имеют тенденцию к ухудшению за счет увеличения болевого синдрома и нестабильности локтевого сустава. При выполнении артропластики локтевого сустава у больных с тяжелыми последствиями травмы локтевого сустава отличные и хорошие результаты составили 38,1 \%, 47,62 \% - удовлетворительные и 14,28 \% - неудовлетворительные. Эндопротезирование локтевого сустава является наиболее действенным средством в лечении тяжелых посттравматических деформаций и анкилозов локтевого сустава и позволяет получить отличные и хорошие результаты лечения в 85,72 \% случаев. Оптимальным для лечения тяжелых посттравматических деформаций и анкилозов локтевого сустава является использование полуразомкнутых конструкций эндопротезов, что позволяет проводить раннюю дозированную активную реабилитацию. Нестабильность локтевого сустава, которая наблюдалась у всех пациентов после артропластики и наличие остаточной сгибательно-разгибательной контрактуры локтевого сустава, являются предпосылками к быстрому прогрессированию остеоартроза.
\end{abstract}

Ключевые слова: артропластика; эндопротезирование; локтевой сустав. 